\title{
PENGARUH KONSENTRASI EKSTRAK BAWANG MERAH DAN LAMA PERENDAMAN STEK JAMBU AIR MADU VARIETAS DELI HIJAU (Syzygium aqueum L.)
}

\section{Effects of Onion Extract Concentration and Soaking Time on Cuttings Guava Green Honey of Green Deli Variety (Syzygium aqueum L.)}

\author{
Jinjing Ario Silitonga, T. Edy Sabli dan Fathurrahman, F. \\ Program Studi Agroteknologi, Fakultas Pertanian Universitas Islam Riau \\ Email : fathur@agr.uir.ac.id \\ [Diterima: September 2019; Disetujui: November 2019]
}

\begin{abstract}
This study was conducted to determine the effects of interaction and the main response of the onion extract concentration and soaking time on cuttings guava water honey of green Deli variety (Syzygium aqueum L.). A completely randomized design (CRD) factorial was used in this study, consisting of 2 factors. The first factor was the concentration of onion extract consisting of 4 levels, i.e control, $100 \mathrm{~g}, 300 \mathrm{~g}$, and $500 \mathrm{~g}$ of onion extract per $100 \mathrm{ml}$ water. The second factor was the soaking time which consisted of 4 levels, i.e the soaking time of cuttings 3 hours, 6 hours, 9 hours, and 12 hours. The parameters observed were percentage of cuttings grown, age of germination days after planting, number of shoots, number of roots, longest root length, root volume. Observational data were analyzed statistically and continued with Tukey's HSD tests $(p<0.05)$. The results showed the interaction of onion extract concentration and soaking time had significant effects on the parameters for the percentage of cuttings grown, sprout age, number of shoots, number of roots, longest root length, and root volume. The best treatment was the combination of onion extract $300 \mathrm{~g}$ per $100 \mathrm{ml}$ of water and soaking time on 9 hours.
\end{abstract}

Keywords: Onion Extract, Concentration, Soaking Time, Guava Honey

\begin{abstract}
ABSTRAK
Penelitian ini bertujuan untuk mengetahui pengaruh interaksi dan pengaruh utama konsentrasi ekstak bawang merah dan lama perendaman terhadap tanaman jambu air madu varietas Deli hijau (Syzygium aqueum L.). Rancangan yang digunakan adalah Rancangan Acak Lengkap (RAL) secara faktorial yang terdiri dari 2 faktor. Faktor pertama adalah konsentrasi ekstrak bawang merah yang terdiri 4 taraf yaitu kontrol, $100 \mathrm{~g}, 300 \mathrm{~g}$ dan $500 \mathrm{~g}$ per $100 \mathrm{ml}$ air ekstrak bawang merah. Faktor kedua adalah lama perendaman yang terdiri dari 4 taraf yaitu lama perendaman stek 3 jam, 6 jam, 9 jam dan 12 jam. Parameter yang diamati adalah persentase hidup stek (\%), umur bertunas hari setelah tanam (hst), jumlah tunas (helai), jumlah akar (buah), panjang akar terpanjang $(\mathrm{cm})$, volume akar $\left(\mathrm{cm}^{3}\right)$. Data pengamatan dianalisis secara statistik dan dilanjutkan dengan uji lanjut BNJ pada taraf 5\%. Hasil penelitian menunjukkan interaksi konsentrasi ekstrak bawang merah dan lama perendaman memberikan pengaruh nyata terhadap parameter persentase hidup stek, umur bertunas, jumlah tunas, jumlah akar, panjang akar terpanjang, dan volume akar. Perlakuan terbaik terdapat pada kombinasi perlakuan konsentrasi ekstrak bawang merah 300 gper100 ml air dan lama perendaman 9 jam.
\end{abstract}

Kata kunci: Ekstrak Bawang Merah, Konsentrasi, Lama Perendaman, Jambu Air Madu

\section{PENDAHULUAN}

Jambu air madu Deli hijau (Syzygium aqueum) merupakan salah satu komoditi unggulan terbaru yang mulai banyak dikembangkan oleh petani hortikultura Kota Binjai, Provinsi Sumatera Utara. Jambu ini memiliki ciri - ciri buahnya berbentuk seperti lonceng, dengan warna kulit buah hijau semburat merah. Buah memiliki rasa yang manis seperti madu. Setiap pohon mampu menghasilkan 200-360 buah per pohon per tahun (30-45 $\mathrm{kg}$ per pohon per tahun) (Tim Peneliti, 2012).

Jambu air termasuk salah satu jenis tanaman buah-buahan yang mengandung 
cukup banyak gizi, sehingga sangat disukai oleh sebagian besar masyarakat. Jambu air madu deli merupakan salah satu kultivar unggulan yang merupakan varietas introduksi dari negara Taiwan dengan nama Jade Rose Aple yang sudah lama berkembang $( \pm 10$ tahun) di Sumatera Utara. Jambu air ini menghasilkan buah yang memiliki nilai ekonomis tinggi karena selain rasanya enak juga mengandung gizi yang cukup tinggi serta lengkap. Menurut Balai Pengawasan dan Sertifikasi Benih IV Dinas Pertanian Sumatera Utara Medan (2012) kandungan gizi dalam 100 $\mathrm{g}$ buah jambu air madu deli terdapat kadar air $81,59 \%$, tingkat kemanisan 12,4 brix, kadar vitamin C 210,463 mg per 100g, tekstur daging $0,830 \mathrm{~g}$ per $\mathrm{mm}^{2}$. (Tarigan $\mathrm{dkk}, 2015$ ).

Tanaman jambu air madu varietas deli hijau dapat diperbanyak secara generatif (biji) dan vegetatif (stek, cangkok, okulasi). Perbanyakan tanaman dengan biji sering mengecewakan karena umur berbuah lama juga sering terjadi penyimpangan sifat-sifat pohon induknya. Perbanyakan vegetatif pada tanaman buah-buahan dimaksud untuk mempertahankan sifat induk yang unggul, memperpendek masa vegetatif, sehingga tanaman tersebut dapat lebih cepat berproduksi. Salah satu perbanyakan vegetatif yang dapat dilakukan untuk memperbanyak jambu madu ialah melalui stek. (Anwarudin, dkk. 1985).

Salah satu ZPT alami yang dapat digunakan adalah ekstrak umbi bawang merah (Allium cepa L.). Sebagai pengganti auksin sintesis dapat digunakan bawang merah (Ependi, 2009). Menurut Rahayu dan Berlian (1999), umbi bawang merah mengandung vitamin B1, Thiamin, riboflavin, asam nikotinat, serta mengandung ZPT auksin dan rhizokalin yang dapat merangsang pertumbuhan akar. Iskandar dan Pronoto (1993) dalam Kusdijanto (1998) menyatakan bahwa ekstrak bawang merah mengandung ZPT yang mempunyai peranan seperti Asam Indol Asetat (IAA) dapat memacu inisiasi akar.

Pada umumnya untuk memperbanyak stek tanaman jambu madu air varietas deli hijau (Syzygium aqueum) selama ini menggunakan zat pengatur tumbuh (ZPT) sintesis seperti ZPT Atonik, ZPT Rootone-F, dan lain - lain. Zat pengatur tumbuh sintesis berguna untuk merangsang pertumbuhan stek, tetapi efektifitas dari zat pengatur tumbuh sintesis belum tentu sama terhadap berbagai sumber stek tanaman. Selain itu harga dari zat pengatur tumbuh sintesis yang mahal menjadi suatu masalah untuk perbanyakan tanaman secara vegetatif. Untuk itu perlu dilakukan usaha dengan beralih menggunakan zat pengatur tumbuh (ZPT) alami dari bawang merah.

Saat ini belum ada rekomendasi tentang penggunaan zat pengatur tumbuh (ZPT) dari bawang merah. Oleh karena itu, perlu dilakukan penelitian tentang pemberian konsentrasi ekstrak bawang merah dan lama perendaman bahan stek tanaman jambu madu untuk mempercepat terbentuknya akar pada stek tanaman jambu madu, sehingga akan didapatkan bibit tanaman jambu madu yang pertumbuhannya sehat dan cepat.

Permasalahan yang ditemui adalah berapa konsentrasi ekstrak bawang merah dan lama perendaman yang diperlukan, sehingga dapat mempengaruhi pertumbuhan stek jambu madu untuk mendapatkan hasil yang baik. Perendaman harus memperhatikan beberapa hal, diantaranya ialah konsentrasinya. Lama perendaman akan berpengaruh terhadap banyaknya ZPT yang diserap oleh tanaman, sehingga apabila konsentrasinya tidak tepat maka akan dapat menghambat pertumbuhan akar, tunas, sehingga daun menguning dan gugur atau stek tidak tumbuh.

Berdasarkan uraian diatas, penulis telah melaksanakan penelitian dengan judul "Pengaruh konsentrasi ekstrak bawang merah dan lama perendaman stek tanaman jambu air madu varietas Deli hijau (Syzygium aqueum L.)".

\section{BAHAN DAN METODE}

Penelitian ini telah dilaksanakan di kebun percobaan Fakultas Petanian Universitas Islam Riau, Jalan Kaharuddin Nasution KM 11 No. 113 Marpoyan Kelurahan Air Dingin, Kecamatan Bukit Raya, Kota Pekanbaru. Penelitian ini dilaksanakan selama 4 Bulan, Terhitung dari bulan Desember 2018 sampai Maret 2019.

Bahan yang digunakan dalam penelitian ini terdiri dari pucuk stek jambu air madu Deli hijau adalah bawang merah, media stek, polybag ukuran $15 \times 20 \mathrm{~cm}$, Dithane M-45, karet gelang dan cat hijau. Alat - alat yang digunakan adalah blender, kayu penyangga, ember, plastik bening (poly ethyline) ukuran 
$20 \times 30 \mathrm{~cm}$, handsprayer, meteran, timbangan elektrik, seng, gunting setek dan kamera.

Rancangan ini menggunakan Rancangan Acak Lengkap (RAL) faktorial yang terdiri dari 2 faktor, faktor pertama yaitu Pemberian Ekstrak Bawang Merah (B) terdiri dari 4 taraf dan Lama Perendaman $(\mathrm{P})$ terdiri dari 4 taraf perlakuan sehingga terdapat 16 kombinasi perlakuan dengan 3 ulangan maka ada 48 unit percobaan. Masing - masing unit terdiri dari 6 tanaman dan 2 dijadikan sebagai sampel, sehingga keseluruhan tanaman 288.

Data pengamatan terakhir dianalisis secara statistik dengan menggunakan analisis sidik ragam (ANOVA). Apabila F hitung yang diperoleh lebih besar dari $\mathrm{F}$ tabel, maka dilanjutkan dengan melakukan uji lanjut Beda Nyata Jujur (BNJ) pada taraf 5\%.

Tabel 1. Rerata Persentase Hidup Stek Jambu Air Madu Deli Hijau Perlakuan Konsentrasi Ekstra Bawang Merah dan Lama Perendaman (\%).

\begin{tabular}{|c|c|c|c|c|c|}
\hline \multirow{2}{*}{$\begin{array}{c}\text { Perlakuan B } \\
\text { (gram) }\end{array}$} & \multicolumn{4}{|c|}{ Perlakuan P (jam) } & \multirow{2}{*}{ Rerata } \\
\hline & P1 (3) & P2 (6) & P3 (9) & P4 (12) & \\
\hline B0 (0) & $38,89 \mathrm{bc}$ & $33,33 \mathrm{c}$ & $33,33 \mathrm{c}$ & $33,33 \mathrm{c}$ & $34,72 \mathrm{~b}$ \\
\hline B1 (100) & $50,00 \mathrm{~b}$ & $50,00 \mathrm{~b}$ & $50,00 \mathrm{~b}$ & $44,44 \mathrm{bc}$ & $48,61 \mathrm{a}$ \\
\hline B2 (300) & $50,00 \mathrm{~b}$ & $55,55 \mathrm{ab}$ & 66,66 a & $44,44 \mathrm{bc}$ & 54,16 a \\
\hline B3 (500) & $50,00 \mathrm{~b}$ & $50,00 \mathrm{~b}$ & $50,00 \mathrm{~b}$ & $44,44 \mathrm{bc}$ & $48,61 \mathrm{a}$ \\
\hline Rerata & $47,22 \mathrm{ab}$ & $47,22 \mathrm{ab}$ & $50,00 \mathrm{a}$ & $41,67 \mathrm{~b}$ & \\
\hline
\end{tabular}

$\mathrm{KK}=11,56 \% \quad$ BNJ BP $=11,90 \quad$ BNJ B \& $\mathrm{P}=5,95$

Angka-angka pada kolom dan baris yang diikuti oleh huruf kecil yang sama menunjukkan tidak berbeda nyata menurut uji beda nyata jujur (BNJ) pada taraf $5 \%$.

Pada Tabel 1, memperlihatkan bahwa interaksi konsentrasi ekstrak bawang merah dan lama perendaman memberikan pengaruh terhadap persentase hidup stek, dimana perlakuan yang terbaik dihasilkan oleh kombinasi perlakuan konsentrasi ekstrak bawang merah $300 \mathrm{~g}$ per $100 \mathrm{ml}$ air dan lama perendaman stek 9 jam (B2P3) dengan persentase hidup stek $66,66 \%$, tidak berbeda nyata pada perlakuan (B2P2) 55,55\% dan berbeda nyata dengan kombinasi perlakuan lainnya. Sedangkan persentase hidup stek terendah dihasilkan oleh perlakuan tanpa konsentrasi ekstrak bawang merah (B0P4), yaitu $33,33 \%$.

Tingginya persentase hidup stek tanaman jambu air madu varietas Deli hijau yang dihasilkan oleh perlakuan B2P3, hal ini dikarenakan melalui konsentrasi ekstrak bawang merah $300 \mathrm{~g}$ per $100 \mathrm{ml}$ air sesuai dengan yang dibutuhkan dengan demikian dapat mempengaruhi pertambahan panjang batang, pertumbuhan, diferensiasi dan percabangan akar untuk pertumbuhan stek

\section{HASIL DAN PEMBAHASAN}

\section{Persentase Hidup Stek (\%)}

Hasil dari pengamatan terhadap persentase hidup stek tanaman jambu air madu varietas Deli hijau setelah dilakukan analisis ragam memperlihatkan bahwa secara interaksi maupun secara pengaruh utama perlakuan konsentrasi ekstrak bawang merah dan lama perendaman memberikan pengaruh nyata terhadap persentase hidup stek tanaman jambu air madu varietas Deli hijau. Rerata hasil pengamatan terhadap persentase hidup stek setelah dilakukan uji BNJ pada taraf $5 \%$ dapat dilihat pada Tabel 1 . tanaman jambu air madu. Kemudian dikombinasikan dengan lama perendaman stek selama 9 jam yang merupakan perlakuan yang tepat. Hal ini dikarenakan bawang merah mengandung auksin, vitamin, dan mineral lain yang mampu meningkatkan pertumbuhan stek tanaman jambu madu deli hijau termasuk terbentuknya akar dan melalui perendaman selama 9 jam air yang masuk kedalam stek sesuai dengan yang dibutuhkan dengan demikian dapat menunjang pertumbuhan stek tanaman jambu air madu Deli hijau.

Rendahnya persentase hidup stek tanaman jambu madu pada kombinasi perlakuan B0P4 hal ini disebabkan dengan tidak adanya pemberian ekstrak bawang merah dan dengan lama perendaman stek selama 12 jam air yang diserap oleh stek telah melebihi dari yang dibutuhkan sehingga dapat melemahkan kemampuan kerja stek yang pada akhirnya dapat mempengaruhi persentase hidup stek. 


\section{Umur Bertunas (hari)}

Hasil pengamatan terhadap umur bertunas pada stek jambu air madu varietas Deli hijau setelah dilakukan analisis ragam memperlihatkan bahwa secara interaksi maupun secara pengaruh utama perlakuan konsentrasi eksrak bawang merah dan lama perendaman memberikan pengaruh nyata terhadap umur bertunas pada stek jambu madu. Rerata hasil pengamatan umur muncul tunas dilakukan uji BNJ pada taraf $5 \%$ dapat dilihat pada Tabel 2.

Pada Tabel 2 diatas memperlihatkan bahwa interakasi konsentrasi ekstrak bawang merah dan lama perendaman memberikan pengaruh terhadap umur bertunas stek jambu air madu varietas Deli hijau, dimana perlakuan yang terbaik dihasilkan oleh kombinasi perlakuan konsentrasi ekstrak bawang merah $300 \mathrm{~g}$ per $100 \mathrm{ml}$ air dan lama perendaman 9 jam (B2P3) dengan umur bertunas 21,17 hst, tidak berbeda nyata pada perlakuan (B2P2) yaitu 22,17 hst dan berbeda nyata dengan perlakuan lainnya. Umur bertunas stek jambu air madu deli hijau terlama dihasilkan oleh perlakuan tanpa konsentrasi ekstrak bawang merah dan lama perendaman 9 jam (B0P4) yaitu 28,83 .

Tabel 2. Rerata Umur Bertunas Stek Jambu Air Madu Deli Hijau Perlakuan Konsentrasi Ekstrak Bawang Merah dan Lama Perendaman (HST).

\begin{tabular}{|c|c|c|c|c|c|}
\hline \multirow{2}{*}{$\begin{array}{l}\text { Perlakuan B } \\
\text { (gram) }\end{array}$} & \multicolumn{4}{|c|}{ Perlakuan P (jam) } & \multirow{2}{*}{ Rerata } \\
\hline & P1 (3) & P2 (6) & P3 (9) & P4 (12) & \\
\hline B0 (0) & $27,17 \mathrm{~d}$ & $27,67 \mathrm{de}$ & $28,33 \mathrm{e}$ & $28,83 \mathrm{e}$ & $28,00 \mathrm{~d}$ \\
\hline B1 (100) & $25,00 \mathrm{c}$ & $24,17 \mathrm{bc}$ & $23,33 \mathrm{~b}$ & $25,83 \mathrm{~cd}$ & $24,58 \mathrm{~b}$ \\
\hline B2 (300) & $23,33 \mathrm{~b}$ & $22,17 \mathrm{a}$ & $21,17 \mathrm{a}$ & $25,00 \mathrm{c}$ & $22,92 \mathrm{a}$ \\
\hline B3 (500) & $25,50 \mathrm{c}$ & $24,83 \mathrm{c}$ & $24,00 \mathrm{bc}$ & $26,67 \mathrm{~d}$ & $25,25 \mathrm{c}$ \\
\hline Rerata & $25,25 \mathrm{~b}$ & $24,71 \mathrm{ab}$ & $24,21 \mathrm{a}$ & $26,58 \mathrm{c}$ & \\
\hline
\end{tabular}

$\mathrm{KK}=1,99 \% \quad$ BNJ BP $=1,11 \quad$ BNJ B \& P $=0,55$

Angka-angka pada kolom dan baris yang diikuti oleh huruf kecil yang sama menunjukkan tidak berbeda nyata menurut uji beda nyata jujur (BNJ) pada taraf $5 \%$.

Cepatnya umur bertunas yang dihasilkan oleh perlakuan B2P3 dikarenakan konsentrasi ekstrak bawang merah yang digunakan tepat sehingga ZPT yang terkandung dalam ekstrak bawang merah dapat memacu proses diferensiasi sel-sel pada stek, dengan demikian dapat mempercepat umur bertunas dan lama perendaman stek selama 9 jam merupakan perlakuan yang tepat dikarenakan air yang masuk kedalam stek sesuai dengan yang dibutuhkan, dengan demikian dapat menunjang dalam proses perombakan cadangan makanan yang terdapat dalam stek sehingga dapat memacu untuk tumbuhnya tunas. Pembentukan tunas sangat penting sebagai tahap awal pembentukan primordial daun dimana daun merupakan organ tanaman yang memiliki jumlah klorofil terbesar yang berfungsi sebagai tempat terjadinya fotosintesis untuk menghasilkan karbohidrat sebagai sumber makanan (Febriana, 2009).

Lambatnya umur bertunas pada kombinasi perlakuan B0P4 disebabkan oleh tidak adanya pemberian konsentrasi ekstrak bawang merah dan lamanya perendaman stek selama 12 jam yang menyebabkan air yang diserap oleh stek melebihi dari yang dibutuhkan, sehingga dapat melemahkan kemampuan kerja sel dalam stek yang pada akhirnya dapat mempengaruhi tumbuhnya tunas. Umbi bawang merah diyakini mengandung hormon auksin karena dibagian atas cakram yang merupakan batang pokok tidak sempurna akan terbentuk umbi lapis karena adanya adanya pembengkakan kelopak yang saling membungkus. Pada bagian dalam umbi lapis tersebut terdapat tunas yang dapat tumbuh menjadi tanaman baru (Wibowo, 1988). Menurut Handayani, (2006), air dalam jumlah yang tinggi, elastisitas dinding sel menjadi tinggi sehingga meningkatkan rasiko sel mengalami dormansi karena elastisitas sel dipengaruhi oleh pemasaman pada dinding sel dan menyebabkan sel mangalamikejenuhan basa sehingga terjadi pembusukan.

Menurut Hasanah dan Nintya (2007), jumlah air juga mengindikasikan senyawasenyawa lainnya seperti nutrisi dan hormone didalam sel tumbuhan. Keseimbangan antara air, nutrient dan hormone dalam sel memberikan efek maksimal terhadap jaringan maristem apikal ujung dan koleoptil yang ditandai dengan munculnya akar dan tunas dalam waktu singkat. Jumlah yang tidak 
seimbang pada akhirnya menyebabkan pemunculan akar dan tunas lebih lama.

\section{Jumlah Tunas (Helai)}

Hasil pengamatan terhadap jumlah tunas pada stek jambu air madu varietas Deli hijau setelah dilakukan analisis ragam memperlihatkan bahwa secara interaksi maupun secara pengaruh utama perlakuan konsentrasi eksrak bawang merah dan lama perendaman memberikan pengaruh nyata terhadap jumlah tunas pada stek jambu madu. Rerata hasil pengamatan jumlah tunas dilakukan uji BNJ pada taraf $5 \%$ dapat dilihat pada Tabel 3 .
Pada Tabel 3 diatas memperlihatkan bahwa interaksi konsentrasi ekstrak bawang merah dan lama perendaman memberikan pengaruh terhadap jumlah tunas, dimana perlakuan yang terbaik dihasilkan oleh kombinasi perlakuan konsentrasi ekstrak bawang merah $300 \mathrm{~g}$ per $100 \mathrm{ml}$ air dan lama perendaman 9 jam (B2P3) dengan jumlah tunas 7,40 dan berbeda nyata dengan kombinasi perlakuan lainnya. Sedangkan jumlah tunas yang paling sedikit dihasilkan oleh perlakuan tanpa konsentrasi ekstrak bawang merah dan lama perendaman 12 jam (B0P4) yaitu 2,00 helai.

Tabel 3. Rerata Jumlah Tunas Stek Jambu Air Madu Deli Hijau dengan Perlakuan Konsentrasi Ekstrak Bawang Merah dan Lama Perendaman (Helai).

\begin{tabular}{llllll}
\hline \multirow{2}{*}{$\begin{array}{c}\text { Perlakuan B } \\
\text { gram })\end{array}$} & \multicolumn{4}{c}{ Perlakuan P (jam) } & \multirow{2}{*}{ Rerata } \\
\cline { 2 - 4 } & P1 (3) & P2 (6) & P3 (9) & P4 (12) & $2,54 \mathrm{~d}$ \\
B0 (0) & $3,50 \mathrm{e}$ & $2,50 \mathrm{f}$ & $2,17 \mathrm{f}$ & $2,00 \mathrm{f}$ & $4,54 \mathrm{~b}$ \\
B1 $(100)$ & $4,50 \mathrm{de}$ & $4,83 \mathrm{~d}$ & $5,50 \mathrm{c}$ & $3,83 \mathrm{e}$ & $6,05 \mathrm{a}$ \\
B2 $(300)$ & $6,30 \mathrm{~b}$ & $5,50 \mathrm{c}$ & $7,40 \mathrm{a}$ & $5,00 \mathrm{~cd}$ & $4,21 \mathrm{c}$ \\
B3 $(500)$ & $4,00 \mathrm{e}$ & $4,50 \mathrm{de}$ & $4,83 \mathrm{~d}$ & $3,50 \mathrm{e}$ & $3,58 \mathrm{c}$ \\
\hline Rerata & $4,58 \mathrm{~b}$ & $4,33 \mathrm{~b}$ & $4,98 \mathrm{a}$ & & \\
\hline
\end{tabular}

$\mathrm{KK}=6,00 \% \quad$ BNJ BP $=0,58 \quad$ BNJ B \& $\mathrm{P}=0,29$

Angka-angka pada kolom dan baris yang diikuti oleh huruf kecil yang sama menunjukkan tidak berbeda nyata menurut uji beda nyata jujur (BNJ) pada taraf 5\%.

Banyaknya jumlah tunas yang dihasilkan pada kombinasi perlakuan (B2P4) yaitu 7,40 helai, hal ini dikarenakan pada kombinasi perlakuan tersebut merupakan perlakuan yang tepat, dimana dengan konsentrasi ekstrak bawang merah $300 \mathrm{~g}$ per $100 \mathrm{ml}$ air dan lama perendaman 9 jam dapat memberikan keseimbangan stek dalam konsentrasi ekstrak bawang merah dan dalam menyerap air, sehingga pada kombinasi perlakuan tersebut dapat menghasilkan jumlah tunas terbanyak.

\section{Jumlah Akar (Buah)}

Hasil pengamatan jumlah akar pada stek jambu air madu varietas Deli hijau setelah dilakukan analisis ragam memperlihatkan bahwa secara interaksi maupun secara pengaruh utama perlakuan konsentrasi eksrak bawang merah dan lama perendaman memberikan pengaruh nyata terhadap jumlah akar pada stek jambu madu air. Rerata hasil pengamatan jumlah tunas dilakukan uji BNJ pada taraf $5 \%$ dapat dilihat pada Tabel 4 .

Banyaknya jumlah akar yang dihasilkan oleh kombinasi perlakuan (B2P3) yaitu 15,33 buah, hal ini dikarenakan pada kombinasi perlakuan tersebut merupakan perlakuan yang tepat, dimana dengan konsentrasi ekstrak bawang merah $300 \mathrm{~g}$ per $100 \mathrm{ml}$ air dan perendaman selama 9 jam dapat memberikan keseimbangan stek dalam konsentrasi ekstrak bawang merah dan dalam menyerap air sehingga pada kombinasi perlakuan tersebut dapat menghasilkan jumlah akar terbanyak, pemberian ekstrak bawang merah pada konsentrasi tertentu dapat menimbulkan pengaruh yang tertentu terhadap pertumbuhan dan metabolisme tanaman yang pada akhirnya dapat mempengaruhi pertumbuhan akar, dimana akar yang dihasilkan semakin banyak.

Umbi bawang merah mengandung zat pengatur tumbuh auksin untuk merangsang pertumbuhan akar dan vitamin B1 (thiamin) yang berperan penting dalam perombakan karbohidrat menjadi energy dalam metabolisme tanaman. Sedikitnya jumlah akar pada perlakuan B0P4 yaitu 8,00 buah, dikarenakan tidak adanya pemberian konsentrasi ekstrak bawang merah pada stek, dimana dalam bawang merah mengandung auksin. Auksin bertindak sebagai pendorong awal proses terbentuknya akar pada stek. Tidak adanya pemberian konsentrasi ekstrak bawang merah pada stek tanaman jambu air madu mengakibatkan jumlah akar lebih sedikit. 
Tabel 4. Rerata Jumlah Akar Stek Jambu Air Madu Deli Hijau dengan Perlakuan Konsentrasi Ekstrak Bawang Merah dan Lama Perendaman (Buah).

\begin{tabular}{lcccrr}
\hline \multirow{2}{*}{$\begin{array}{c}\text { Perlakuan B } \\
\text { gram })\end{array}$} & P1 (3) & P2 $(6)$ & P3 $(9)$ & P4 (12) & \multirow{2}{*}{ Rerata } \\
\cline { 2 - 5 } B0 $(0)$ & $9,33 \mathrm{e}$ & $9,00 \mathrm{ef}$ & $8,33 \mathrm{ef}$ & $8,00 \mathrm{f}$ & $8,67 \mathrm{~d}$ \\
B1 $(100)$ & $10,67 \mathrm{~d}$ & $11,50 \mathrm{~cd}$ & $12,33 \mathrm{c}$ & $10,17 \mathrm{de}$ & $11,17 \mathrm{~b}$ \\
B2 $(300)$ & $13,50 \mathrm{~b}$ & $14,50 \mathrm{ab}$ & $15,33 \mathrm{a}$ & $13,00 \mathrm{bc}$ & $14,08 \mathrm{a}$ \\
B3 $(500)$ & $10,00 \mathrm{de}$ & $10,50 \mathrm{~d}$ & $11,83 \mathrm{c}$ & $9,33 \mathrm{e}$ & $10,42 \mathrm{c}$ \\
\hline Rerata & $10,88 \mathrm{~b}$ & $11,38 \mathrm{~b}$ & $11,96 \mathrm{a}$ & $10,13 \mathrm{c}$ & \\
\hline
\end{tabular}

$\mathrm{KK}=4,60 \% \quad \mathrm{BNJ} \mathrm{BP}=1,13 \quad$ BNJ B \& $\mathrm{P}=0,56$

Angka-angka pada kolom dan baris yang diikuti oleh huruf kecil yang sama menunjukkan tidak berbeda nyata menurut uji beda nyata jujur (BNJ) pada taraf $5 \%$.

\section{Panjang Akar Terpanjang (cm)}

Hasil dari pengamatan panjang akar terpanjang pada stek jambu air madu varietas madu Deli hijau setelah dilakukan analisis ragam memperlihatkan bahwa secara interaksi maupun secara pengaruh utama pemberian konsentrasi ekstrak bawang merah dan lama perendaman memberikan pengaruh pengaruh nyata terhadap panjang akar terpanjang pada stek tanaman jambu air madu Deli hijau. Rerata hasil pengamatan terhadap panjang akar terpanjang setelah dilakukan uji BNJ pada taraf $5 \%$ dapat dilihat pada Tabel 5.

Tabel 5. Rerata Panjang Akar Terpanjang Stek Jambu Air Madu Deli Hijau dengan Perlakuan Konsentrasi Ekstrak Bawang Merah dan Lama Perendaman $(\mathrm{Cm})$.

\begin{tabular}{|c|c|c|c|c|c|}
\hline \multirow{2}{*}{$\begin{array}{l}\text { Perlakuan B } \\
\text { (gram) }\end{array}$} & \multicolumn{4}{|c|}{ Perlakuan P (jam) } & \multirow{2}{*}{ Rerata } \\
\hline & P1 (3) & $\mathrm{P} 2(6)$ & P3 (9) & P4 (12) & \\
\hline B0 (0) & $16,77 \mathrm{c}$ & $16,03 \mathrm{~cd}$ & $15,77 \mathrm{~cd}$ & $15,13 \mathrm{~d}$ & $15,93 \mathrm{c}$ \\
\hline B1 (100) & $17,90 \mathrm{bc}$ & $18,73 \mathrm{~b}$ & $18,90 \mathrm{~b}$ & $16,63 \mathrm{c}$ & $18,04 \mathrm{~b}$ \\
\hline B2 (300) & $18,20 \mathrm{bc}$ & $18,77 \mathrm{~b}$ & $20,77 \mathrm{a}$ & $18,00 \mathrm{bc}$ & $18,93 \mathrm{a}$ \\
\hline B3 (500) & $17,47 \mathrm{bc}$ & $17,87 \mathrm{bc}$ & $18,70 \mathrm{~b}$ & $16,13 \mathrm{~cd}$ & $17,54 \mathrm{~b}$ \\
\hline Rerata & $17,58 \mathrm{~b}$ & $17,85 \mathrm{ab}$ & $18,53 \mathrm{a}$ & $16,48 \mathrm{c}$ & \\
\hline
\end{tabular}

Angka-angka pada kolom dan baris yang diikuti oleh huruf kecil yang sama menunjukkan tidak berbeda nyata menurut uji beda nyata jujur (BNJ) pada taraf 5\%.

Interaksi konsentrasi ekstrak bawang merah dan lama perendaman memberikan pengaruh terhadap panjang akar terpanjang, dimana perlakuan terbaik dihasilkan oleh kombinasi perlakuan konsentrasi ekstrak bawang merah $300 \mathrm{~g}$ per $100 \mathrm{ml}$ air dan lama perendaman 9 jam (B2P3) dengan panjang akar terpanjang $20,77 \mathrm{~cm}$ dan berbeda nyata dengan kombinasi perlakuan lainnya. Sedangkan panjang akar terpanjang terendah dihasilkan oleh perlakuan tanpa pemberian konsentrasi ekstrak bawang merah dan lama perendaman 12 jam (B0P4) yaitu $15,13 \mathrm{~cm}$.

Akar merupakan bagian yang tidak terpisahkan dari tanaman dan mempunyai fungsi yang sama pentingnya dengan bagian atas tanaman. Panjangnya akar yang dihasilkan pada perlakuan (B2P3), hal ini disebabkan dengan pemberian perlakuan tersebut merupakan perlakuan yang tepat dimana stek jambu air madu deli hijau menggunakan konsentrasi ekstrak bawang merah yang sesuai dengan yang dibutuhkan dan lama perendaman yang sesuai dengan yang dibutuhkan juga, sehingga dapat menyerap larutan ekstrak bawang merah secara baik dengan demikian dapat aktif untuk merangsang pertumbuhan stek dan menghasilkan panjang akar terpanjang.

Penghambatan pertumbuhan akar pada kombinasi perlakuan (B0P4), hal ini diduga dipengaruhi oleh kontrol endogen dalam tanaman. Penghambat tersebut disebabkan oleh adanya senyawa penghambat perakaran yang berupa senyawa phenol dan mangan (Jarvis, 1986) dalam (Pamungkas dkk, 2009). Senyawa phenol yakni monophenol dan mangan merupakan faktor penting dalam aktifitas enzim IAA oksadase. Monophenol merupakan subtansi penghambat pertumbuhan karena pengaruhnya dalam meningkatkan aktifitas IAA oksidase, sehinga akan menurunkan kandungan auksin dalam tubuh tanaman. 


\section{Volume Akar $\left(\mathbf{c m}^{3}\right)$}

Hasil dari pengamatan volume aka pada stek jambu air madu varietas madu Deli hijau setelah dilakukan analisis ragam memperlihatkan bahwa secara interaksi maupun secara pengaruh utama pemberian konsentrasi ekstrak bawang merah dan lama perendaman memberikan pengaruh pengaruh nyata terhadap volume akar pada stek tanaman jambu air madu Deli hijau. Rerata hasil pengamatan terhadap volume akar setelah dilakukan uji BNJ pada taraf $5 \%$ dapat dilihat pada Tabel 6.

Data pada Tabel 6 menunjukkan bahwa secara interaksi pemberian konsentrasi ekstrak bawang merah dan lama perendaman memberikan pengaruh terhadap volume akar stek tanaman jambu air madu varietas deli hijau. Kombinasi yang menghasilkan volume akar tertinggi yaitu konsentrasi ekstrak bawang merah $300 \mathrm{~g}$ per $100 \mathrm{ml}$ air dan lama perendaman 9 jam (B2P3) yaitu 8,00, yang tidak berbeda nyata dengan perlakuan (B3P3) yaitu 7,33. Perlakuan yang menghasilkan volume akar terendah yaitu kombinasi tanpa pemberian konsentrasi ekstrak bawang merah dan lama perendaman 12 jam menit (B0P4) dengan volume akar 4,00.

Tabel 6. Rerata Volume Akar pada Stek Jambu Air Madu Deli Hijau dengan Perlakuan Konsentrasi Ekstrak Bawang Merah dan Lama Perendaman $\left(\mathrm{cm}^{3}\right)$.

\begin{tabular}{llllll}
\hline \multirow{2}{*}{$\begin{array}{c}\text { Perlakuan B } \\
(\text { gram })\end{array}$} & P1 (3) & P2 $(6)$ & P3 $(9)$ & P4 (12) & \multirow{2}{*}{ Rerata } \\
\hline B0 $(0)$ & $4,83 \mathrm{~cd}$ & $4,33 \mathrm{~d}$ & $4,17 \mathrm{~d}$ & $4,00 \mathrm{~d}$ & $4,33 \mathrm{c}$ \\
B1 $(100)$ & $5,67 \mathrm{c}$ & $6,17 \mathrm{bc}$ & $6,33 \mathrm{bc}$ & $5,00 \mathrm{~cd}$ & $5,79 \mathrm{~b}$ \\
B2 $(300)$ & $6,33 \mathrm{bc}$ & $6,83 \mathrm{~b}$ & $8,00 \mathrm{a}$ & $5,50 \mathrm{~cd}$ & $6,67 \mathrm{a}$ \\
B3 $(500)$ & $5,67 \mathrm{c}$ & $6,17 \mathrm{bc}$ & $7,33 \mathrm{ab}$ & $4,67 \mathrm{~d}$ & $5,96 \mathrm{~b}$ \\
\hline Rerata & $5,63 \mathrm{~b}$ & $5,88 \mathrm{~b}$ & $6,46 \mathrm{a}$ & $4,79 \mathrm{c}$ & \\
\hline
\end{tabular}

$\mathrm{KK}=6,95 \% \quad \mathrm{BNJ} \mathrm{BP}=0,87 \quad$ BNJ B \& $\mathrm{P}=0,44$

Angka-angka pada kolom dan baris yang diikuti oleh huruf kecil yang sama menunjukkan tidak berbeda nyata menurut uji beda nyata jujur (BNJ) pada taraf $5 \%$.

Tingginya volume akar pada perlakuan (B2P3) dikarekan kombinasi ektrak bawang merah dan lama perendaman yang sesuai akan merangsang pertumbuhan akar dengan jumlah banyak dan meningkatkan pertumbuhan yang lebih cepat dibandingkan perlakuan tanpa pemberian ekstrak bawang merah. Hasil volume akar dipengaruhi oleh jumlah daun dan jumlah akar jika jumlah daun dan akar dihasilkan tinggi maka proses fotosintesis akar lebih tinggi dikarenkan jumlah daun yang lebih banyak mengakibatakan jumlah akar dan volume akar meningkat.

Rendahnya volume akar yang dihasilkan perlakuan (B0P4) disebabkan tidak adanya pemberian zat pengatur tumbuh (ekstrak bawang merah), sehingga pertumbuhan akar menjadi lebih lambat ditambah dan perendaman yang berlebihan menyebabkan terganggunya pertumbuhan pada setek jambu air madu deli hijau. Zat pengatur tumbuh sangat diperlukan oleh tanaman dimana zat pengatur tumbuh dapat meningkatkan aktivitas fisiologi tanaman sehingga dapat mempertinggi pemanfaatan unsur hara dan cahaya. Zat pengatur tumbuh yang dihasilkan sendiri oleh tanaman disebut fitohormon sedangkan yang buatan disebut zat pengatur tumbuh sintetik. Auksin ini sudah digunakan secara luas dan komersil bidang pertanian, dimana batang, pucuk dan akar tumbuhtumbuhan memperlihatkan respon terhadap auksin, yaitu peningkatan laju pertumbuhan pada konsentrasi yang optimal dan penurunan pertumbuhan terjadi pada konsentrasi yang terlalu rendah dan terlalu tinggi (Aslamyah, 2002).

Bawang merah merupakan salah satu komoditas hortikultura. Ekstrak bawang merah mengandung zat pengatur tumbuh yang mempunyai peranan mirip Asam Indol Asetat (IAA). Asam Indol Asetat (IAA) adalah auksin yang paling aktif untuk berbagai tanaman dan berperan penting dalam pemacuan pertumbuhan yang optimal (Husein dan Saraswati, 2010).

\section{KESIMPULAN}

Berdasarkan penelitian yang telah dilaksanakan, dapat disimpulkan bahwa Interaksi konsentrasi ekstrak bawang merah dan lama perendaman memberikan pengaruh nyata terhadap semua parameter yang diamati yaitu persentase hidup stek, umur bertunas, 
jumlah tunas, jumlah akar, panjang akar terpanjang, dan volume akar. Perlakuan terbaik terdapat pada kombinasi perlakuan konsentrasi ekstrak bawang merah $300 \mathrm{~g}$ per $100 \mathrm{ml}$ air dan lama perendaman 9 jam (B2P3).

Pengaruh utama konsentrasi ekstrak bawang merah memberikan pengaruh nyata terhadap semua parameter yang diamati yaitu persentase hidup stek, umur bertunas, jumlah tunas, jumlah akar, panjang akar terpanjang, dan volume akar. Perlakuan terbaik konsentrasi ekstrak bawang merah $300 \mathrm{~g}$ per $100 \mathrm{ml}$ air (B2).

Pengaruh utama lama perendaman nyata terhadap semua parameter yang diamati yaitu persentase hidup stek, umur bertunas, jumlah tunas, jumlah akar, panjang akar terpanjang, dan volume akar. Perlakuan terbaik lama perendaman selama 9 jam (P3).

\section{DAFTAR PUSTAKA}

Anonim. 2014. Basis Data Statistik Pertanian. Data Produksi Jambu Air Provinsi Riau Tahun 2010-2014. Online pada: http://aplikasi.pertanian.go.id/bdspperne wkom.asp. Diakses Tanggal 22 Januari 2018.

Febriana, S. 2009. Pengaruh konsentrasi ZPT dan Panjang stek terhadap pembentukan akar dan tunas pada stek apokad (Persea americana Mill). Skripsi (Tidak Dipublikasikan). Institut Pertanian Bogor, Bogor.

Gunawan, C.C.R. 2016. Pengaruh Induksi dan Metode Aplikasi Zat Pengatur Tumbuh Rootone-F Terhadap Induksi Akar dan Tunas Stek Dadap Merah (Eryhrina crystagalli). Skripsi (Tidak Dipublikasikan). Institut Pertanian Bogor, Bogor.

Handayani, T. 2006. Pembibitan Secara StekMini Tanaman Melati (Jasminum sambac L. Aiton). Jurnal Sains dan Teknologi Indonesia, 8(1): 21-25.

Hartman, H. T, D. E Kester and F. T. Davies Jr. 1990. Plant Propagation, Principles and Practies. 5 th ed. Prentice Hall. Engle - Wood Cuff, New Jersey.

Marfirani, M., Y. S. Rahayu, dan E. Ratnasari. 2014. Pengaruh Pemberian Berbagai Konsentrasi Filtrat Umbi Bawang Merah Dan Rootone-F Terhadap Pertumbuhan Stek Melati Rato Ebu. Jurnal Lentera Bio, 3(1): 73-76.
Nurlaeni, Y. dan M. I. Surya. 2015. Respon Stek Pucuk Camelia Japonica terhadap Pemberian Zat Pengatur Tumbuh Organik. Dalam Prosiding Seminar Nasional Masyarakat Biodiversifikasi Indonesia. Volume 1 Nomor 5 Agustus 2015. Hal 1211-1215.

Pamungkas, F.E, Darmanti, dan S. Raharjo. 2012. Pengaruh Konsentrasi dan Lama Perendaman dalam Supenatant Kultur Baccilus Sp.2 Duuc-BR-K1.3 terhadap Pertumbuhan Stek Horizontal Batang Jarak Pagar. Jurnal Sains Dan Matematika, 17(3): 131-140.

Tarigan, V., C. Hanum, dan R. Danamik. 2015. Pertumbuhan Vegetatif dan Generatif Jambu Air (Syzygium samarangense (Blume) Merr, \& Perry) Vegetatif Deli Hijau dengan Perlakuan ZPT dan Media Tanam. Jurnal Dinamika Fakultas Pertanian, 3(2): 740 - 747.

Wibowo, S. 1988. Budidaya Bawang: Bawang Putih, Bawang Merah, dan Bawang Bombay. Penebar Swadaya, Jakarta. 